\title{
Economic Impacts of Municipal Recycling
}

\author{
Jared Creason and Michael J. Podolsky*
}

\begin{abstract}
Recycling efforts recovered about 55 million tons of municipal solid waste through approximately 9,000 curbside recycling programs and about 10,000 drop-off centers in 1996 (U.S. Environmental Protection Agency 1998). We investigate economic impacts of this activity using state-level data wherever possible. Our results indicate that, while recycling tends to increase waste management costs, the spending creates an important economic stimulus for the processing and collection industries. These industries can have a small positive effect on economic development. Local officials should be cognizant of the total economic impact of recycling as well as its consequences for the distribution of income.
\end{abstract}

\section{INTRODUCTION}

Postconsumer recycled materials have been an important feedstock for many industries for many years. A total of 210 million tons of municipal solid waste was generated in the United States in 1996, or about 4.3 pounds per person per day. ${ }^{1}$ Recycling efforts recovered about 27 percent of that total, or 55 million tons, through approximately 9,000 curbside recycling programs and about 10,000 drop-off centers (U.S. Environmental Protection Agency 1998). A nationwide industry has developed to process, sort, and clean these materials. This industry has operations in all 50 states, is in most cases locally operated, and is compatible with many people's concepts of environmentally sustainable development. Yet analysis of the economic impacts of recycling at the regional or national level is limited.

Municipalities, regional solid waste commissions, and state governments would like to know what the economic impact of recycling is on their communities. In a controversial New York Times Magazine article, Tierney (1996) asserted that recycling was uneconomical because the program costs exceed disposal costs. ${ }^{2}$ Ackerman (1997) suggested that supporters of recycling must look "beyond the bottom line" of program costs to environmental amenity values and the role of recycling in economic development. Our results indicate that, while recycling tends to increase waste management costs, the spending creates an important economic stimulus for the processing and collection industries. These industries can

\footnotetext{
"National Center for Environmental Economics, U.S. Environmental Protection Agency, Washington. D.C.; and Case Western Reserve University, Cleveland, $\mathrm{OH}$. All views expressed in this paper are those of the authors only and do not necessarily reflect the official position of the U.S. Environmental Protection Agency or Case Western Reserve University School of Law. The authors wish to thank Scott Palmer, George Garland, Scott Loveridge, and three anonymous referees for helpful suggestions, as well as David Folz for providing data. A presentation based on an early version of this paper was made at the 1998 National Implan Users Conference in Washington, D.C. ${ }^{1}$ This total includes all waste, including yard trimmings and other compost.

2For a review of the impact of Tierney (1996) see Aquino (1997).
} 
have a small positive effect on economic development. Local officials should be cognizant of the total economic impact of recycling as well as its consequences for the distribution of income.

This paper estimates the economic impacts of recycling. We focus on the recyclables processing sector: sorted, cleaned raw materials are the output, made from consumer waste sources. The processing sector is linked to the related industries that collect recyclables and other inputs and to industries that produce final goods using recycled feedstock. We investigate the backward and forward economic linkages of the processing sector, paying special attention to regional differences. The results show the distribution of economic impacts associated with the transfer of income. ${ }^{3}$

We employ an Input-Output (I-O) framework, and report results of 42 state-level models. State-level models are employed to account for differences in prices of recyclables and processed materials, as well as differences in the (opportunity) costs of incineration and landfilling. I-O analysis is complicated by the fact that recyclables processing firms do not report data under a single SIC code, and the I-O matrices must be adjusted for the new products and industries. The remaining sections of this paper are as follows: The next section of the paper reviews the literature; the third section provides an economic model of the recycling industry; the fourth section describes the data; the fifth section presents the estimated values of output and employment for recycling collection and related industries as well as an economic impact analysis of the recycling sector; the sixth section briefly outlines relevant forward linkages in the manufacturing sector; and the final section is the summary and conclusion.

\section{REVIEW OF SELECTED RECYCLING/ECONOMIC IMPACT LITERATURE}

Butterfield and Kubursi (1993) studied the incremental employment effects of several alternative scenarios involving recycling initiatives in the U.S. and Canada, largely focusing on the paper industry. Their paper presents an example of one way that the I-O tables can be expanded to account for recycling activity. Butterfield and Kubursi (1993) show, in general, employment losses from various recycling programs, driven by the fact that old newspaper feedstocks are to a large extent imported to Canada from the U.S. and therefore imported raw materials are substituted for domestic pulpwood production.

The U.S. Environmental Protection Agency (EPA) funded a study called the Recycling Economic Information Project to recommend a methodology for conducting a study of the U.S. recycling and reuse industries (Northeast Recycling

\footnotetext{
${ }^{3}$ These results should not be interpreted as a benefit-cost analysis. A benefit-cost analysis would be primarily concerned with estimating changes in social welfare measures, such as consumer's surplus, and real resource costs (See also Northeast Recycling Council 1998, p. E-9), while this study measures changes in regional economic output and employment. There are also many ramifications of recycling, such as changes in energy and water use, air and water emissions, and use of other resources such as landfill space and individuals' time, that are not addressed here.
} 
Council 1998). The report contains information on 45 different categories of recycling and reuse businesses, including collection, processing, wholesale and retail reuse, and support categories. We extend this report by estimating impacts in the processing sector using reported prices and quantities.

Economic impact analysis of the type presented here has been done for the recycling industries in selected states. The Iowa Departments of Economic Development and Natural Resources jointly produced a study of recycling-related industries in the state of Iowa (Recycle Iowa Program 1997). The Iowa study estimated recycling industry impacts by creating 15 interdependent industries representing collection, processing, and end use of recyclables and recycled products. Recyclables collection, employment, and gross sales data were obtained from a survey of firms in recycling-related industries. The Iowa study sets a precedent for focusing on the processing sector: "the appropriate point of economic impact analysis is at the processor level - the point at which initial value is added to the recycled commodities" (Recycle Iowa Program 1997, p. 4-3). To do this, the Iowa study assumed that the value of losses to the waste haulers and landfill industries are exactly offset by the increased activity in recyclables collection. The Iowa study examined the use of recyclable materials and found significant end use of all materials except glass. The Iowa study also estimated impacts associated with the industries that manufacture recycling equipment.

The focus of our paper is on the recyclable materials processing industry, but at both a state and national level. However, our paper does not include the detailed treatments of the specific processing industries in the Iowa study. We also drop the assumption that increased collection costs of recycling exactly offset the lost tipping fees and trash collection costs. Finally, our paper uses calculations based on Type II multipliers, which are generally smaller in comparison with the Type III multipliers used in the Iowa study. ${ }^{4}$ Type II multipliers base calculations of induced economic effects on changes in employee income, rather than employment status as in the Type III multiplier. We feel this is appropriate for most analyses that examine businesses that hire people locally, rather than bring in workers from outside the region.

The Minnesota Office of Environmental Assistance conducted a study of recycling and businesses that use recycled feedstocks in the state of Minnesota (Gjerde et al. 1997). This study is not directly comparable with the others because it focuses on the manufacturers of end-use products that utilize recycled feedstocks. As such, it profiles businesses that demand recycled materials, but the activity highlighted is not the recyclable material processing activity where value is first added. Gjerde et al. (1997) estimate the economic impact of recycling by eliminating those end-use businesses that indicated a high reliance on recycled

\footnotetext{
${ }^{4}$ Type III multipliers base the induced effects calculation on the number of jobs, while Type II multipliers are based on the amount of income generated. For example, the Type II output multiplier for the sanitary services and steam supply sector is 1.88 , whereas the Type III multiplier is 2.08 (source: IMPLAN model calculations using 1994 data for the state of Iowa).
} 
feedstocks. However, the highly aggregated model used does not automatically link these manufacturers explicitly to recyclable material processors and, therefore, the results are difficult to evaluate.

\section{AN ECONOMIC MODEL OF RECYCLING INDUSTRY LINKAGES}

To estimate the economic impact of recycling industries, we use the Implan $^{\mathrm{TM}}$ data and modeling system. Recycling is not a typical industry represented in the national I-O matrices by a single SIC code. Our model, therefore, has two parts. Outside the Implan ${ }^{\mathrm{TM}}$ framework, we calculate net revenues for three interdependent activities: landfills and collection, program administration, and processing. The calculations done outside the Implan ${ }^{\mathrm{TM}}$ framework address the unique aspects of the recycling industry. Second, these net revenues are entered into the I-O model, and the Implan ${ }^{\mathrm{TM}}$ system calculates economic impacts to the rest of the economy. In this way we account for the unique structure of the recycling industry without double counting.

\section{Three Sectors}

Recyclables processors are important for two reasons; first, the processing stage is the stage at which significant economic value is created, and second, this sector presents the most difficult challenges for modeling. Processors obtain recyclable materials from municipalities and sell cleaned recyclables for reuse. Processors typically receive a per ton fee from municipalities. A certain percentage of the materials is unrecyclable and must be removed and disposed of by landfills.

Consider three types of materials, such as newspapers, aluminum, and glass, indexed by $i$. Let $P_{i}$ be the price paid by end users to processors for material $i\left(P_{i}>0\right) ; P_{i}^{\prime}$ is the price processors pay for material $i$. $P_{i}^{\prime}$ is generally expected to be positive, implying that recyclable materials have a cost to processors, but the model can accommodate instances where processors must be paid to accept a particular material. Let $Q_{i}$ be the quantity of material $i$, measured in tons; $L_{i}$ is the percent of $Q_{i}$ that is actually not recyclable and is removed through processing and then landfilled $\left(0<\mathrm{L}_{\mathrm{i}}<1\right) ; \mathrm{F}$ is the per ton processing fee, and $\mathrm{T}$ is the per ton cost of landfill disposal for all materials $(\mathrm{F}, \mathrm{T}>0)$. Thus, the net revenue in the processing sector is

$$
R_{P}=\sum_{i}\left(P_{i}-P_{i}^{\prime}\right) Q_{i}+F \sum_{i} Q_{i}-T \sum_{i} L_{i} Q_{i} .
$$

Municipalities gain financially from the sale of recyclable materials and avoided disposal fees on that material collected for recycling. Municipalities also incur collection costs and must pay fees to processors. Changes in local waste management program revenues are given by:

$$
R_{M}=\sum_{i} P_{i}^{\prime} Q_{i}+\left(C_{T}+T\right) \sum_{i} Q_{i}-\left(C_{R}+F\right) \sum_{i} Q_{i},
$$

where $C_{T}$ and $C_{R}$ are the cost of collecting municipal waste and recyclables, respectively. 
Two changes in particular affect the landfill and collection sector. First, there is a change from collecting all trash to collecting recyclables and garbage. Second, landfills receive the materials that the processors are unable to recycle. Changes in landfills and collection revenues are given by:

$$
R_{C}=\left(C_{R}-C_{T}\right) \sum_{i} Q_{i}+T \sum_{i}\left(L_{i}-1\right) Q_{i}
$$

\section{DATA}

The most extensive and most widely used source of recycling data is a report published by the EPA (U.S. Environmental Protection Agency 1998). This report contains estimates of quantities of recycled materials, as well as limited information on prices. The EPA report, although providing a comprehensive look at municipal solid waste, has been criticized as a data source for recycling studies such as this one for several reasons. The first criticism concerns the "materials flows" method used for estimating quantities. EPA begins with estimates of the total amounts of municipal solid waste generated each year and applies a percentage representing the portion recovered through recycling and reuse. The remainder is assumed to be discarded. Because of the uncertainties in estimating the percentage factors without the support of measured variables, the resulting estimates can only be taken as a conjecture of the true quantities of recyclable materials collected and processed. The second criticism is that EPA presents national averages and national totals, thereby masking the important regional differences in markets for recycled materials. For example, paper mills and other end users were buying old newspaper feedstock at prices between $\$ 5.00$ per ton (midAtlantic states) and $\$ 47.50$ per ton (south central states) in a two-week period in 1996 (Egan 1996). ${ }^{5}$ This price difference means that in some areas municipalities had to pay processors to take collected recyclables, while in other areas municipalities were getting a significant positive return. One simply cannot do a meaningful economic study using national average prices when regional markets vary so much.

Folz et al. (1998) conducted a national study of municipal recycling. The sample data describe municipal recycling programs in the U.S. based on the 1996 population of U.S. municipalities that were in "primary control" recycling programs. ${ }^{6}$ About two-thirds of these are entirely voluntary programs, while others include mandatory recycling of some products. All programs include singlefamily residences and most also include multifamily dwellings, some commercial businesses, and industrial firms. The most widely collected material is newspaper, but over 91 percent of programs pick up glass and aluminum also. Crews pick up an average of 3,700 tons of newspaper, 700 tons of glass, and 139 tons of aluminum

\footnotetext{
5 State-level estimates may vary due to different measurement techniques. We use consistent data sources to control for this source of error.

${ }^{6}$ In the 30 states with less than 120 city-run recycling programs, all the cities were contacted. In the 14 states with more than 120 city-run recycling programs, a stratified sample, based on population, was drawn. The response rate was 49 percent. The remaining six states do not have city-run recycling programs, and are excluded from the analysis.
} 
per municipality each year. Most municipalities send these materials to privately owned and operated materials recovery facilities for processing. The data also indicate the broad appeal of recycling at the municipal level. Support for programs was ranked "strong" or "very strong" by residents, city or town councils, mayors, directors of public works, and schools - every group except the business community, whose support was termed "moderate" overall. The data also include average tipping fees at landfills and incinerators.

The primary advantage of the Folz et al. (1998) data is that they provide direct estimates of recycling for each state. Still, certain limitations do exist. Municipalities receiving recycling services from another level of government (e.g., county) were excluded from the sample. In some cases, this left out information for localities in entire states (e.g., Indiana). As for all data developed through selfreporting, there is always some concern regarding accuracy. However, the national estimates of the quantity of material recycled based on aggregating across states were very similar to those contained in the EPA report (U.S. Environmental Protection Agency 1998).

\section{RESULTS}

\section{Direct Effects}

Table 1 shows the values of recyclable collection services and materials that we estimated for this study: the net value $(R)$ of materials sold by recyclable materials processors; the value of materials losses (L) as recyclables are cleaned and prepared for use by manufacturers; the value of the cost of recycling collection $\left(C_{R}\right)$; the processing fee $(F)$ that is paid to processors for accepting materials from municipalities or the cost municipalities incur if they process materials through their own facility; the value of the reduction in nonrecyclable waste disposal services for collection $\left(\mathrm{C}_{\mathrm{T}}\right)$ and for disposal $(\mathrm{T})$. We estimated revenues associated with newspaper, aluminum cans, and glass for each of the 42 states. All data represent 1996 annual totals.

\section{TABLE 1}

Variables Used, Geographic Scale, and Sources

\begin{tabular}{llll}
\hline Variable & Name & Scale & Source \\
\hline $\mathrm{P}$ & Processor Prices & Regional & Recycling Times \\
$\mathrm{P}^{\prime}$ & Producer Prices & Regional & Recycling Times \\
$\mathrm{Q}_{\mathrm{i}}$ & Tons of Material i & State & Folz \\
$\mathrm{F}$ & Fees $(\$ /$ ton) & National & EPA \\
$\mathrm{T}$ & Tipping Fees & State & Folz \\
$\mathrm{C}_{\mathrm{R}}$ & Collection Cost, Recyclables & National & EPA \\
$\mathrm{C}_{\mathrm{T}}$ & Collection Cost, Municipal Waste & National & EPA \\
$\mathrm{L}_{\mathrm{i}}$ & Loss Rate for Material i & National & Garland \\
\hline
\end{tabular}

To estimate 1996 values of recyclable materials collected and produced, we use an average regional price for each type of material and estimated quantities for each state. We multiplied estimates of materials collected per capita from Folz 
et al. (1998) by estimates of the population served in each state. We estimated service population as the total 1996 state population (U.S. Census Bureau estimates), multiplied by the percent served by municipal recycling programs (U.S. Environmental Protection Agency 1998), and again by participation rates (Folz et al. 1998). Loss rates for each of the materials were taken from Garland (1998). Prices for each type of material for each state are based on the regional average "end user" and "processor" prices reported in Recycling Times (Egan 1996).

Several sources were used to obtain needed cost data for the two components of waste disposal services, collection and disposal, for nonrecyclable waste. These values were used to estimate revenues in each of the various waste management-based sectors in the economy. The EPA provided per ton estimates for the collection costs of nonrecyclable waste $(\$ 72.45)$ and recyclables $(\$ 139.24)$ and presented an estimate of the per ton fee paid to recycling processors or the cost municipalities incur if they process materials themselves (\$86.00) (U.S. Environmental Protection Agency 1998). ${ }^{7}$ Folz et al. (1998) provided information on the tipping fees charged at landfills and/or incinerators serving individual jurisdictions. Weighted average tipping fees were constructed using the percentage of waste transported to landfills and incinerators, respectively, reported in Goldstein (1997).

Table 2 shows values for Equations 1, 2, and 3 for each of 42 states. The second column gives the value of aluminum, glass, and newspaper given by Equation 1. The third column reports the result of Equation 2, representing the effect on municipal governments. With rare exceptions, the costs of recycling programs exceed revenues (as captured in Equation 2), hence the values in this column are negative. The five states for which the revenues from recycled materials exceed the cost are Arkansas, Delaware, Mississippi, New York, and Virginia. Part of the explanation lies in the fact that these states all collect relatively more aluminum and less newspaper and glass than other states. ${ }^{8}$ The fourth column gives the result of Equation 3. Recycling programs generally add to the cost of collection, hence the numbers in this column are positive with the exception of the state of Connecticut, which has the second highest average tipping fees in the country. ${ }^{9}$

Summing the values of Equations 1-3 for each state gives the total direct economic effect associated with recycling for each state. These estimates are shown in Figure 1. The five states with the highest totals are Arkansas, Mississippi, Virginia, New York, and Delaware, the same states where governments' sales of recyclables exceed governments' costs. Again, this is due primarily to higher reported values for aluminum collection relative to the lower value materials.

${ }^{7}$ Franklin et al. (1997) provide estimates based on engineering cost estimates (\$1996) assuming curbside collection for average single-family households generating 52 total pounds of waste per week (43.1 pounds for disposal; 7.51 pounds for curbside recycling; 1.37 pounds for drop-off/buyback programs). Several recycling program configurations are presented. We chose the "Base Case Curbside Recycling" configuration, as it most closely approximates the materials included in our analysis. Drop-off/buyback programs are assumed to be costless to municipalities. The processing fee is based on a facility processing 54 tons per day operating 260 days per year. ${ }^{8}$ For the nation as a whole, aluminum makes up only about 8 percent (by weight) of the total recovery of aluminum, glass, and newspaper. But for these five states together, aluminum makes up about 29 percent (by weight) of the total (Folz et al. 1998).

${ }^{9} \mathrm{New}$ Jersey has the highest average tipping fees in the nation, but has higher recyclables collection rates that compensate firms in the waste collection and landfills sector. 
TABLE 2

Direct Economic Effects of Municipal Recycling Programs (Dollars)

\begin{tabular}{|c|c|c|c|}
\hline State & $\begin{array}{c}\text { Equation 1: } \\
\text { Net Revenues of Recyclables } \\
\text { Processing Sector }\end{array}$ & $\begin{array}{c}\text { Equation 2: } \\
\text { Net Program } \\
\text { Revenues (Costs) }\end{array}$ & $\begin{array}{c}\text { Equation 3: } \\
\text { Net Revenues of } \\
\text { Collection Sector }\end{array}$ \\
\hline$\overline{\mathrm{AL}}$ & $1,215,450$ & $(1,165,217)$ & 463,979 \\
\hline $\mathrm{AZ}$ & $7,329,331$ & $(6,519,430)$ & $2,976,498$ \\
\hline $\mathrm{AR}$ & $12,211,897$ & $10,171,851$ & $1,274,880$ \\
\hline CA & $380,122,440$ & $(346,818,216)$ & $130,575,871$ \\
\hline $\mathrm{CO}$ & $11,545,087$ & $(12,086,943)$ & $5,477,814$ \\
\hline CT & $27,867,170$ & $(2,549,839)$ & $(224,346)$ \\
\hline $\mathrm{DE}$ & 202,770 & 35,615 & 24,276 \\
\hline FL & $24,420,834$ & $(7,151,667)$ & $4,812,300$ \\
\hline GA & $5,571,163$ & $(4,768,006)$ & $2,354,321$ \\
\hline ID & 197,703 & $(158,236)$ & 75,384 \\
\hline IL & $80,518,441$ & $(74,049,106)$ & $41,050,476$ \\
\hline IA & $4,375,589$ & $(3,448,330)$ & $1,539,111$ \\
\hline KS & $1,621,422$ & $(1,179,590)$ & 633,601 \\
\hline $\mathrm{ME}$ & $5,228,916$ & $(3,331,960)$ & 910,247 \\
\hline MD & $14,402,173$ & $(5,083,112)$ & $3,797,210$ \\
\hline MA & $28,982,853$ & $(14,403,600)$ & $4,169,688$ \\
\hline MI & $48,871,659$ & $(18,052,019)$ & $11,901,303$ \\
\hline MN & $10,829,030$ & $(7,625,212)$ & $2,740,774$ \\
\hline MS & $1,521,163$ & $1,423,630$ & 323,470 \\
\hline MO & $5,242,515$ & $(5,097,460)$ & $2,263,900$ \\
\hline MT & 35,603 & $(33,871)$ & 11,999 \\
\hline NE & $31,454,158$ & $(28,728,420)$ & $12,795,412$ \\
\hline NV & $8,482,243$ & $(8,880,886)$ & $4,101,859$ \\
\hline $\mathrm{NH}$ & $6,074,199$ & $(606,978)$ & $1,152,536$ \\
\hline NJ & $121,680,597$ & $(26,380,578)$ & $5,417,848$ \\
\hline NM & 579,671 & $(391,515)$ & 233,747 \\
\hline NY & $289,177,555$ & $140,661,301$ & $22,429,220$ \\
\hline NC & $7,248,019$ & $(6,476,206)$ & $3,093,393$ \\
\hline ND & 274,762 & $(240,165)$ & 107,111 \\
\hline $\mathrm{OH}$ & $13,989,565$ & $(11,537,191)$ & $5,298,367$ \\
\hline OR & $8,178,216$ & $(7,445,996)$ & $3,042,484$ \\
\hline PA & $37,939,401$ & $(27,052,446)$ & $10,325,664$ \\
\hline RI & $4,112,044$ & $(4,249,196)$ & $1,487,286$ \\
\hline SC & $2,251,921$ & $(1,654,200)$ & 869,793 \\
\hline $\mathrm{TN}$ & $2,331,008$ & $(2,008,201)$ & 931,543 \\
\hline TX & $8,305,300$ & $(3,611,980)$ & $2,294,194$ \\
\hline VT & $1,633,961$ & $(714,366)$ & 280,568 \\
\hline VA & $44,702,691$ & $18,762,070$ & $4,998,506$ \\
\hline WA & $9,898,323$ & $(4,565,276)$ & $1,488,306$ \\
\hline WV & 601,726 & $(166,874)$ & 143,418 \\
\hline WI & $19,538,878$ & $(15,468,107)$ & $7,330,629$ \\
\hline WY & 341,841 & $(257,990)$ & 155,093 \\
\hline
\end{tabular}

Note: Data from the District of Columbia, AK, HI, IN, KY, LA, OK, SD, and UT are unavailable.

Figure 2 also shows total direct economic effects, but in per capita (for the population served) terms. These estimates show less variability in general, and some outliers, such as Nebraska, appear because of a low number of people served. 


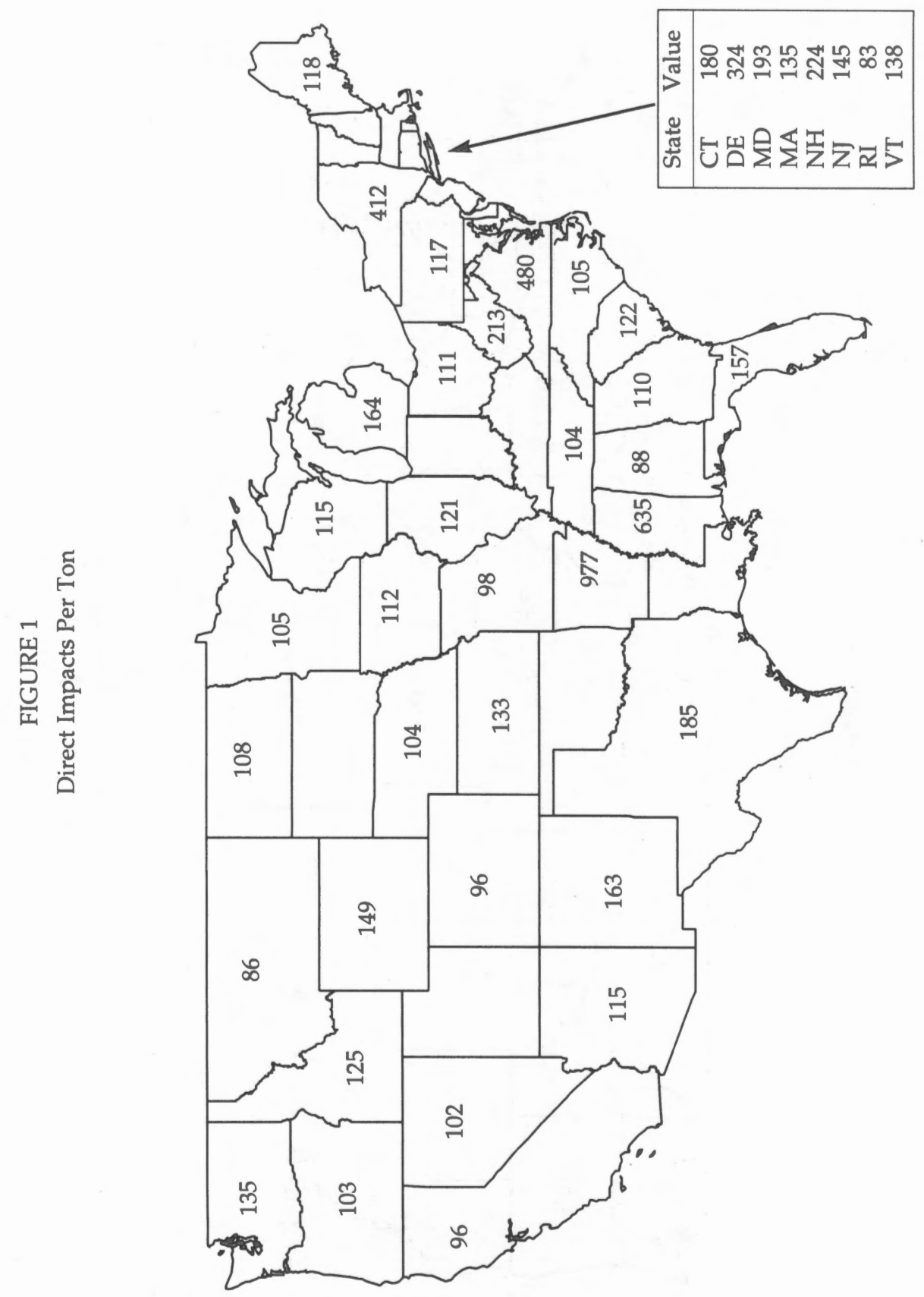




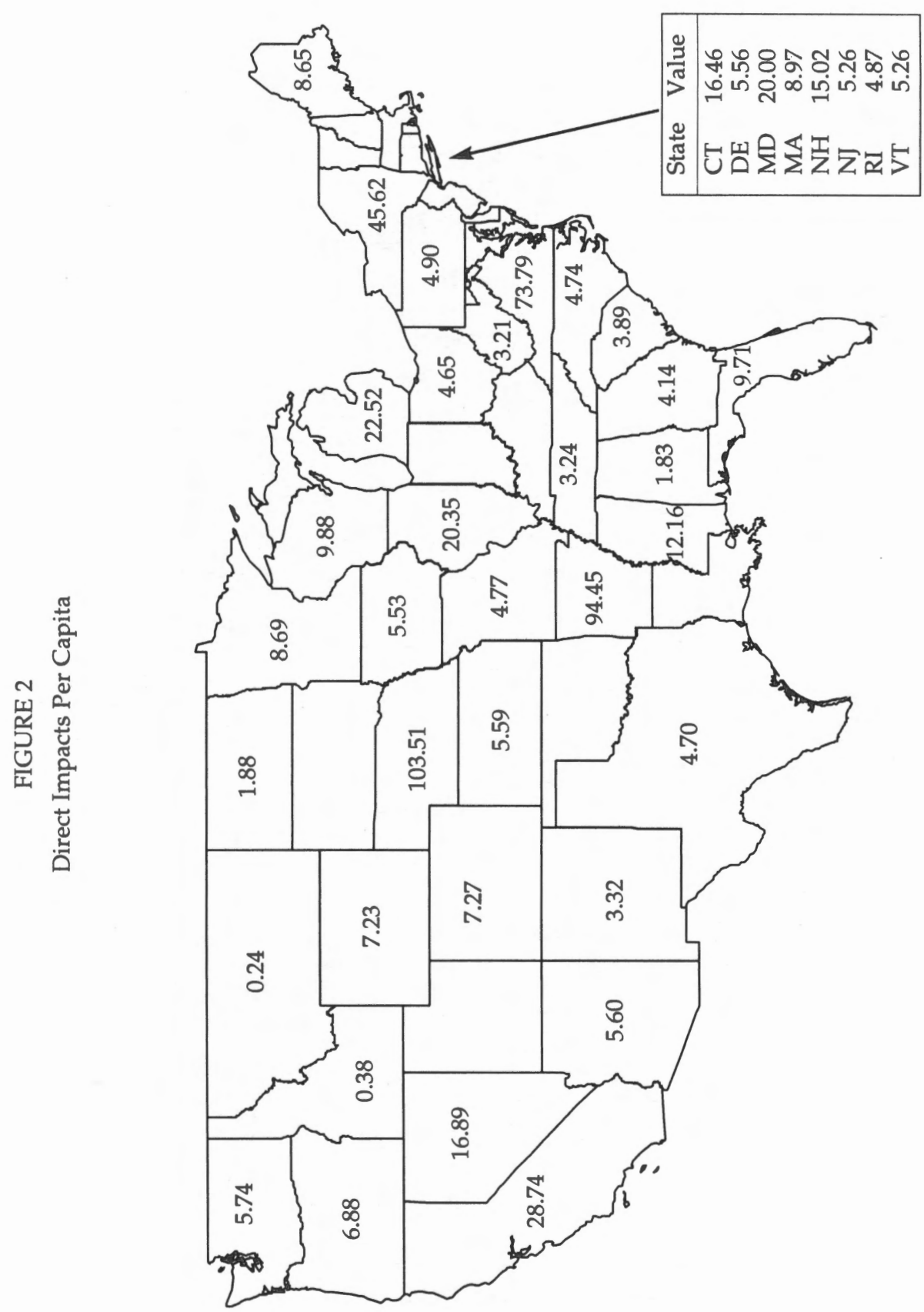




\section{Direct, Indirect, and Induced Effects and Employment Results}

The revenue changes shown in Table 2 can be used to estimate a broader measure of regional economic activity, including patterns of worker spending and firms' demands for material inputs. We used the Implan ${ }^{\mathrm{TM}}$ model in conjunction with 1994 Implan ${ }^{\mathrm{TM}}$ data to drive separate economic impact analyses for each of 42 states. Implan ${ }^{\mathrm{TM}}$ calculates total economic impacts, including direct, indirect, and induced effects. Indirect effects capture the demand for inputs other than those captured by Equations 1-3, while induced effects include the effects of workers' spending. Results measure the total value of economic output and levels of employment for each state that is supported by recycling activities. The analyses cover the impact of processors, the impact of processing workers, the impact of increased taxes, and the impact of changes in landfill collections.

\section{Impact of Processors}

To represent the recyclables processing sector, we examined the materials inputs used by five industries that are similar in that they process large quantities of low-value materials using relatively labor-intensive processes. We averaged the cost coefficients for inputs that appeared in at least three of the five similar industries to create a materials inputs list for a generalized firm-recognizing that we had already accounted for the linkages that were unique to recycling activities through Equations 1-3. This group was imported to each state model to estimate the indirect effects. Induced effects for the recycling processors are estimated by taking the value-added coefficients from the materials inputs vector we derived, scaling these to each state's level of processing activity, and entering the result as an impact on middle-income household spending. The sum of direct, indirect, and induced effects associated with the recyclables processing industry is shown in the second column of Table $3 .^{10}$

\section{Impact of Program Administration}

Table 2 shows that municipal recycling programs generally spend more than they take in in revenues. We assume that taxes must be increased as a result. To simulate the economic impact of increased taxes, we estimate the economic impact of a corresponding decrease in middle-income consumer spending on goods and services. By doing so, we implicitly assume that governments pass on the cost (revenue) of recycling programs to their constituents through taxes, levies, fees, or special assessments. The sum of direct, indirect, and induced effects resulting from spending changes is shown in the third column of Table $3{ }^{11}$

\footnotetext{
${ }^{10}$ Labor costs are included in the I-O model's "value added" category. Input costs and value added identically sum to 1 . We apply a factor of 0.75 to the value-added coefficient to approximate employee compensation (Minnesota Implan Group 1997, p. 201).

${ }^{11}$ Alternatively, one could model the effect of a change in state and local spending of the same sign and direction. This is a constant tax scenario, carrying the implication that municipalities will scale other services to compensate for the net loss or gain from recycling.
} 
TABLE 3

Total Economic Output Results: 1996 Annual Estimates (Dollars)

\begin{tabular}{|c|c|c|c|c|}
\hline State & Recyclables Processors & Spending & Collection & Total \\
\hline $\mathrm{AL}$ & $1,626,138$ & $(1,592,434)$ & 870,749 & 904,453 \\
\hline $\mathrm{AZ}$ & $9,823,677$ & $(9,289,540)$ & $5,591,457$ & $6,125,594$ \\
\hline $\mathrm{AR}$ & $16,652,682$ & $14,201,854$ & $2,613,304$ & $33,467,840$ \\
\hline CA & $545,513,933$ & $(529,168,322)$ & $275,660,657$ & $292,006,268$ \\
\hline $\mathrm{CO}$ & $16,442,021$ & $(18,635,107)$ & $11,348,321$ & $9,155,235$ \\
\hline CT & $34,914,851$ & $(3,595,855)$ & $(429,538)$ & $30,889,458$ \\
\hline DE & 238,303 & 47,138 & 40,981 & 326,422 \\
\hline FL & $34,328,207$ & $(10,665,124)$ & $9,212,903$ & $32,875,986$ \\
\hline GA & $8,088,976$ & $(7,200,604)$ & $4,613,299$ & $5,501,671$ \\
\hline ID & 254,655 & $(211,474)$ & 144,107 & 187,288 \\
\hline IL & $115,346,984$ & $(116,504,273)$ & $88,359,147$ & $87,201,858$ \\
\hline IA & $5,672,520$ & $(4,858,127)$ & $2,900,831$ & $3,715,224$ \\
\hline KS & $2,145,050$ & $(1,689,830)$ & $1,287,904$ & $1,743,124$ \\
\hline ME & $6,874,919$ & $(4,571,024)$ & $1,564,067$ & $3,867,962$ \\
\hline MD & $19,654,436$ & $(7,416,802)$ & $7,207,956$ & $19,445,590$ \\
\hline MA & $38,103,316$ & $(21,260,192)$ & $8,446,722$ & $25,289,846$ \\
\hline MI & $67,025,635$ & $(26,030,423)$ & $24,407,150$ & $65,402,362$ \\
\hline MN & $15,526,273$ & $(11,638,879)$ & $5,357,937$ & $9,245,331$ \\
\hline MS & $2,014,686$ & $1,916,519$ & 604,083 & $4,535,288$ \\
\hline MO & $7,729,611$ & $(8,121,272)$ & $4,870,931$ & $4,479,270$ \\
\hline MT & 46,325 & $(45,777)$ & 22,605 & 23,153 \\
\hline NE & $40,496,553$ & $(40,818,446)$ & $25,235,979$ & $24,914,086$ \\
\hline NV & $10,147,693$ & $(11,594,134)$ & $7,426,310$ & $5,979,869$ \\
\hline NH & $7,776,014$ & $(841,658)$ & $2,078,971$ & $9,013,327$ \\
\hline NJ & $159,621,675$ & $(37,927,328)$ & 10,278,917 & $131,973,264$ \\
\hline NM & 778,986 & $(553,056)$ & 465,619 & 691,549 \\
\hline NY & $388,144,571$ & $203,882,343$ & $41,353,731$ & $633,380,645$ \\
\hline NC & $10,057,406$ & $(9,327,627)$ & $5,858,652$ & $6,588,431$ \\
\hline ND & 315,616 & $(325,020)$ & 188,315 & 178,911 \\
\hline $\mathrm{OH}$ & $18,565,963$ & $(16,546,534)$ & 10,711,817 & $12,731,246$ \\
\hline OR & $11,709,149$ & $(11,117,250)$ & $6,002,590$ & $6,594,489$ \\
\hline PA & $55,573,505$ & $(42,467,252)$ & $22,649,487$ & $35,755,740$ \\
\hline RI & $4,640,774$ & $(5,572,320)$ & 2,639,112 & $1,707,566$ \\
\hline SC & $2,968,889$ & $(2,243,032)$ & $1,582,114$ & $2,307,971$ \\
\hline $\mathrm{TN}$ & $3,307,777$ & $(3,043,667)$ & $1,953,620$ & $2,217,730$ \\
\hline $\mathrm{TX}$ & $12,321,645$ & $(5,598,269)$ & $4,962,334$ & $11,685,710$ \\
\hline VT & $2,077,923$ & $(964,835)$ & 494,356 & $1,607,444$ \\
\hline VA & $61,742,600$ & $27,084,893$ & $9,723,332$ & $98,550,825$ \\
\hline WA & $13,721,808$ & $(6,684,010)$ & $2,859,618$ & $9,897,416$ \\
\hline WV & 730,259 & $(214,767)$ & 256,087 & 771,579 \\
\hline WI & $26,396,371$ & $(22,358,003)$ & $14,033,628$ & $18,071,996$ \\
\hline WY & 382,912 & $(322,527)$ & 278,040 & 338,425 \\
\hline Avg. & $1,004,525$ & $(957,481)$ & 574,395 & 621,439 \\
\hline
\end{tabular}

Note: Data from the District of Columbia, AK, HI, IN, KY, LA, CK, SD, and UT are unavailable.

\section{Impact of Landfills and Collection}

We assumed that recyclables collection firms, if they are in fact distinct from waste collection, are still captured under the waste collection and disposal sectors present in the model. The results of Equation 3 are entered as a change in revenue. The results are shown in the fourth column of Table 3. 
TABLE 4

Employment Impacts (Jobs)

\begin{tabular}{|c|c|c|c|c|}
\hline State & $\begin{array}{l}\text { Recyclables } \\
\text { Processors }\end{array}$ & Spending & Collection & Total \\
\hline$\overline{\mathrm{AL}}$ & 17 & (17) & 8 & 8 \\
\hline $\mathrm{AZ}$ & 105 & (100) & 50 & 55 \\
\hline AR & 189 & 165 & 24 & 378 \\
\hline CA & 5,118 & $(5,162)$ & 2,162 & 2,117 \\
\hline $\mathrm{CO}$ & 178 & (208) & 102 & 73 \\
\hline $\mathrm{CT}$ & 314 & (33) & (3) & 278 \\
\hline $\mathrm{DE}$ & 2 & 1 & 0 & 3 \\
\hline FL & 367 & (118) & 83 & 332 \\
\hline GA & 83 & (78) & 40 & 46 \\
\hline ID & 3 & (3) & 1 & 2 \\
\hline IL & 1,148 & $(1,203)$ & 726 & 671 \\
\hline IA & 68 & $(60)$ & 28 & 36 \\
\hline KS & 24 & (19) & 12 & 17 \\
\hline ME & 78 & (53) & 15 & 39 \\
\hline MD & 201 & (78) & 62 & 184 \\
\hline MA & 373 & (214) & 68 & 228 \\
\hline MI & 687 & (279) & 207 & 615 \\
\hline MN & 169 & (132) & 49 & 85 \\
\hline MS & 22 & 21 & 5 & 48 \\
\hline MO & 88 & (96) & 46 & 38 \\
\hline MT & 0 & (1) & 0 & (0) \\
\hline $\mathrm{NE}$ & 479 & (485) & 240 & 234 \\
\hline NV & 92 & (99) & 59 & 52 \\
\hline $\mathrm{NH}$ & 85 & (10) & 18 & 94 \\
\hline NJ & 1,422 & (344) & 78 & 1,156 \\
\hline NM & 9 & (6) & 4 & 7 \\
\hline NY & 3,428 & 1,811 & 312 & 5,551 \\
\hline $\mathrm{NC}$ & 107 & (102) & 53 & 58 \\
\hline ND & 4 & (4) & 2 & 2 \\
\hline $\mathrm{OH}$ & 200 & (182) & 93 & 111 \\
\hline OR & 128 & (129) & 56 & 55 \\
\hline PA & 586 & (468) & 197 & 316 \\
\hline RI & 46 & (55) & 21 & 13 \\
\hline $\mathrm{SC}$ & 31 & (24) & 14 & 21 \\
\hline TN & 36 & (34) & 18 & 20 \\
\hline $\mathrm{TX}$ & 128 & (61) & 42 & 109 \\
\hline VT & 24 & (11) & 5 & 17 \\
\hline VA & 655 & 298 & 85 & 1,038 \\
\hline WA & 139 & (71) & 24 & 92 \\
\hline WV & 8 & (2) & 2 & 8 \\
\hline WI & 301 & (264) & 131 & 168 \\
\hline WY & 4 & (4) & 3 & 3 \\
\hline Avg. & 11 & (10) & 5 & 6 \\
\hline
\end{tabular}

Notes: Data from the District of Columbia, AK, HI, IN, KY, LA, OK, SD, UT are unavailable.

\section{Employment Results}

Employment totals and impacts are given in Table 4. The second column gives estimates of the total number of jobs supported by the activities of the recyclables processing industry, including indirect and induced effects. The third column reflects job losses from reduced consumer spending that results from the increased tax burden. The fourth column includes all jobs supported by the increase in collection expenditures. As shown in Tables 3 and 4, the economic 
impact of recycling programs varies from state to state. Recycling results in a transfer of income from consumers to processors and waste collection activities. The overall impact on regional economic output and employment measures is positive, but relatively small (especially for employment totals).

\section{FORWARD LINKAGES}

\section{Newspapers}

The EPA reports that the largest use of old newspapers is in the manufacture of newsprint, which consumed 34 percent of the total (U.S. Environmental Protection Agency 1998). Recycled paperboard was the second most important use, with 21 percent of the market, and exports accounted for 19 percent. All other uses, including construction products, molded pulp products, cellulose insulation, and animal bedding, together used the remaining 26 percent. Geographically, most of this recycling takes place in the North Central states.

The use of recycled newspapers reduces the dependence of pulp mills on the forest products industry. In many cases, this has led to industry relocations. Our data presently allow only a limited and preliminary analysis of this type of regional impact. The Implan ${ }^{\mathrm{TM}}$ software calculates I-O multipliers for the forest products sector of 3.46 and for the logging sector of 3.17. The multiplier for the recycling sector we created above is about 1.75 . Thus, it would seem that substituting recycled feedstocks for virgin pulp (with no countervailing increase in another area, such as tourism) would likely cause decreases in overall levels of economic activity. Unlike the glass and aluminum cases discussed below, pulpwood is a renewable resource with many external effects, such as recreation and water quality values, and a more thorough analysis should account for potential changes in forest profitability and the long-run effects on the resource and future generations.

\section{Glass}

The EPA reports that 78 percent of glass cullet is used to produce new glass. Another 16 percent is used in the manufacture of fiberglass insulation. Exports make up only 2 percent of glass use. Other uses, including construction products and abrasives, use the remainder (U.S. Environmental Protection Agency 1998). As glass containers account for the bulk of glass use, we focus on them. Glass containers contain on average about 27 percent recycled content. With glass, the use of recycled feedstocks does not displace expensive virgin materials (the primary input is sand). Rather, the value in use comes from the reduced energy required to transform recycled feedstocks into new end products. Glass container plants are concentrated in the states of Illinois, Indiana, Ohio, Pennsylvania, and New Jersey. Moreover, the EPA indicates that "Recycled glass is collected in excess of traditional market needs in many areas of the country" (U.S. Environmental Protection Agency 1998, p. 137). 


\section{Aluminum}

The EPA reports that 76 percent of recycled cans are used toward the manufacture of new can sheet (U.S. Environmental Protection Agency 1998). The recycled content of aluminum cans is about 52 percent. Aluminum can recycling takes place mostly in the Great Lakes states and in southern California, Tennessee, and Georgia. As with glass, energy savings are a primary value to end users of recycled aluminum feedstocks. It seems reasonable to assert that industry will only alter their production processes to make use of recycled feedstock if it saves them money. This means lower direct impacts and higher value added for the final goods-producing sector

\section{SUMMARY AND CONCLUSIONS}

This paper uses data from several sources, including a new study of municipal recycling programs across the U.S., to construct individual state models of the economic impact of recycling. The results show that some states enjoy the combination of low landfill tipping fees and strong markets for recyclable materials that give recycling an unambiguous net positive impact on economic output. The results also suggest that in regions where waste disposal services have traditionally received a higher price, recycling may have significant implications for the waste disposal sector since lost tipping fees are not covered by increased collections. In most areas, the net program revenue is negative, indicating that costs to municipalities outweigh the revenues from the sales of recyclables and avoided garbage disposal fees.

Our analysis also serves to illustrate a distinction between benefit-cost analysis and economic impact analysis. From the point of view of a municipal government (and probably most individuals), the reduction in expenditures for waste disposal services is considered a positive impact or benefit. However, from the perspective of the waste disposal services industry, it is a loss of revenue. This result merely highlights the difference between impact analysis and a benefit-cost analysis. Benefit-cost analysis, including real resource costs and monetized benefits, should be used to justify policy decisions based on economic efficiency. Economic impact analysis does not "take sides" on this issue. Economic impact analysis emphasizes the distributive effects of a policy that, depending on the relative weight decision makers place on efficiency versus distribution, may influence the ultimate policy choice.

The analysis contained in this paper suggests some future research that will serve to further enhance economic impact analyses of recycling. First, refining cost estimates for providing recycling and waste disposal services is needed. Current cost data are typically limited to average costs based on model programs. Second, developing a production function for recycling services within the I-O framework is important. While this paper and the Iowa study employ reasonable proxies, a more complete economic impact assessment will require a more accurate assessment of the interaction of recycling with the other sectors comprising 
the I-O matrix. Finally, and perhaps most importantly, supporting data must be developed in order to incorporate impacts such as the displacement of virgin materials and changes in energy use associated with the use of recycled materials in products manufacturing into the economic impact analysis. Estimating such impacts will be useful in assessing environmental changes associated with recycling based on its entire economic impact and may be important for future waste management policy development.

\section{REFERENCES}

Ackerman, Frank. "Recycling: Looking Beyond the Bottom Line." Biocycle 38 (1997), 67-70.

Aquino, John T. "A Recycling 'Pilgrim's Progress': An Anatomy of 'Recycling Is Garbage.'" Waste Age, May 1997.

Butterfield, David, and Atif A. Kubursi. "Regional Economic Effects of Recycling in Ontario." Canadian Journal of Regional Science 16 (1993), 413-431.

Egan, Katherine. "The Markets Page." Recycling Times, various issues, 1996.

Folz, David H., et al. Analysis of National Solid Waste Recycling Programs and Development of Solid Waste Recycling Cost Functions: Descriptive Statistics from Survey No. 2. Oak Ridge, TN: Joint Institute for Energy and Environment, July 1998.

Franklin, William E., Marjorie A. Franklin, Nicholas S. Artz, and Jacob E. Beachy. Solid Waste Management at the Crossroads. Prairie Village, KS: Franklin Associates, Ltd., December 1997.

Garland, George. Memo to author, Tellus Institute, 6 August 1998.

Gjerde, Wayne, et al. Minnesota's Value-Added Recycling Manufacturing Industries: An Economic and Environmental Profile. St. Paul: Minnesota Office of Environmental Assistance, 1997.

Goldstein, Nora. "Biocycle Nationwide Survey: The State of Garbage." Biocycle 38 (1997), 60-67.

Minnesota Implan Group, Inc. Implan ${ }^{\mathrm{TM}}$ System (1994 data and software). Stillwater, MN, 1997.

Northeast Recycling Council (NERC). Recycling Economic Information Project: Final Report. Lexington, KY: Council of State Governments, 1998.

Recycle Iowa Program. Iowa Economic Impacts of Recycling Study. Des Moines, January 1997.

Tierney, John. "Recycling is Garbage." New York Times Magazine, 30 June 1996.

U.S. Environmental Protection Agency. Characterization of Municipal Solid Waste in the United States: 1997 Update. EPA530-R-98-007. Washington, D.C., May 1998. 